\title{
Organizational Commitment and Civil Servants Performance: The Contribution of Intelligence, Local Wisdom and Organizational Culture
}

\author{
Syamsul Bahri, Mansyur Ramly, Achmad Gani, and St. Sukmawati
}

\section{ABSTRACT}

The purpose of this study was to analyze the influence of intelligence, local wisdom, and organizational, culture on organizational commitment, to analyze the influence of potential intelligence, local wisdom and organizational culture on performance, to analyze the effect of organizational commitment on performance, and to analyze the influence of potential intelligence, local wisdom, and culture. The organization through an organizational commitment to performance. The research was carried out at the Wajo District Government with a population of 5,991 employees from 11 SKPD and set a sample of 375 people as respondents based on the Slovin formula. The questionnaire results were analyzed using the Structural Equation Model using AMOS 18 assistance. The results found that organizational culture had a negative and insignificant effect on employee performance. This indicates that the indicators of organizational culture in the form of integrity, identity, responsibility, discipline, and results in orientation are considered to be improved and enhanced in obtaining the realization of work results by employee performance achievements. The organizational culture that has a negative and insignificant effect does not mean that organizational culture is not implemented, but the meaning of the values, rules, and principles of the founders of the organization has undergone a shift to make changes towards achieving work results orientation in supporting employee performance improvement. Without ignoring other variables, namely intelligence, local wisdom, and commitment to performance.

Keywords: Culture, civil servants' performance, commitment, intelligence, local wisdom.

\section{INTRODUCTION}

Responses to the dynamics of government organizations that continue to transform human resources (HR) development, one of the keys to the success of the government in implementing development is to improve human resources to carry out their main tasks and functions well. Government employees as Civil Servants (ASN) are the main driving force of the government to achieve organizational goals. The importance of realizing good governance is inseparable from the contribution of employees who have intelligence, local wisdom, and a good organizational culture to commit to improving their performance in achieving organizational goals [1]. Of course, this is a consideration to be implemented consistently and continuously under the prevailing laws and regulations.

Laws and regulations relating to ASN management, and ASN performance (civil servant), namely the law number 5 of 2014 concerning civil servants, government regulation number 11 of 2017 concerning civil servant management, and government regulation number 30 of 2019 concerning assessment employee performance. The Law Number 5 of 2014 concerning civil servants states that ASN is a profession for civil servants and the government with a work
Submitted : January 30, 2021

Published : February 11, 2021

ISSN: 2507-1076

DOI: $10.24018 /$ ejbmr.2021.6.1.720

\section{S. Bahri*}

Postgraduate School of Indonesian Muslim University Makassar, Indonesia. (e-mail: syamsul.bahri@gmail.com) M. Ramly

Indonesian Muslim University Makassar, Indonesia.

(e-mail: mansyur.ramly@umi.ac.id)

A. Gani

Indonesian Muslim University Makassar, Indonesia.

(e-mail: achmad.gani@umi.ac.id)

S. Sukmawati

Indonesian Muslim University Makassar, Indonesia.

(e-mail: sukmawati@umi.ac.id)

*Corresponding Author agreement that works for government agencies. This is in line with government regulation number 11 of 2017 concerning management of civil servants, in the general provisions article 1 states that the management of civil servants is the management of civil servants to produce employees who are professional, have basic values, professional ethics, free from political intervention, clean from the Corruption, Collusion and Nepotism practice (KKN). Government regulation number 30 of 2019 concerning employee performance appraisal, states that ASN performance assessment is carried out based on objective, measurable, accountable, participatory, and transparent principles. This principle can be assessed in the achievement of work results in quantity, quality, efficiency, effectiveness, and loyalty.

At present, especially the Wajo district government is faced with a crucial problem regarding the implementation of human resource management that is not yet as expected. The fact is that the commitment of employees in carrying out their main duties and functions is not optimal for improving employee performance. The cause of not increasing commitment and increasing performance is inseparable from the influence of intelligence, local wisdom, and unrealized organizational culture so that there is a gap that causes the implementation of human resources 
management in a government organization to not run well. The fact that happened to the Wajo district government, shows that empirically, the condition and ability of employees to improve their performance have not matched expectations with reality. Gaps still often occur in the dynamics of government work related to employee performance.

Empirically it is found that the performance of employees in the Wajo District Government, especially in the Regional Work Units (SKPD) has not contributed according to the realization of the targets that have been set. Based on the Annual Report of each SKPD leader, it shows that their performance achievement is still below $95 \%$ of the set target. The main reason for the performance that has not reached the target set is due to various programs and activities that have not reached the target because some agencies cannot spend the budget in actualizing the programs and activities that have been set, or some are experiencing budget shortages, making it difficult to implement various programs and activities that have been determined, as an assessment of employee performance. More specifically indicated performance data of employees of the recapitulation of the total reporting SKPD documented in reporting regent for the local budget government on Wajo district under the assessment of the work program as follows:

TABLE I: REALIZATION OF CIVIL SERVANTS PERFORMANCE -BASED BUDGET

\begin{tabular}{cc}
\hline \hline Years & $\begin{array}{c}\text { Civil servant performance } \\
\text { (percentage) }\end{array}$ \\
\hline 2015 & 84.16 \\
2016 & 90.55 \\
2017 & 88.18 \\
2018 & 93.22 \\
2019 & 92.74 \\
\hline \hline
\end{tabular}

Table I shows that the percentage of realization of civil servants' performance achievement based on program achievements using the APBD budget in the last 5 years performance achievement is still below $95 \%$ which means that it tends to never reach the target. which is expected to be above $95 \%$ to $100 \%$. This data also shows that during the period 2015 to 2016, civil servants performance has increased from $84.16 \%$ to $90.55 \%$. This increase is because employees are committed to managing government programs and activities properly even though they have not reached the predetermined targets. In 2017, employee performance has decreased because employee commitment is very dependent on leadership policies. In 2018 the actual employee performance increased to $93.22 \%$ and decreased slightly in 2019 to $92.74 \%$. Arguments or facts show that the realization of civil servants performance has decreased due to low organizational commitment which is influenced by intelligence, local wisdom, and applied organizational culture.

The argument for the cause of employee performance has decreased from each SKPD states that many government programs and activities are not completed on time in quantity, quality, efficiency, effectiveness, and resulting job loyalty. Many programs and activities are constrained by several things that affect civil servants' performance. Like what was stated by the Wajo District that the performance of
Government employees so far still needs to be improved, which factually based on the evidence found in the Wajo District Government shows that civil servants performance still needs to be improved, especially concerning the assessment of work results. Wajo District Government employees, in achieving their performance reporting assessment, still need to optimize the organizational achievement of the targets that have been set, especially those related to the achievement of results in quantity seen from the number of work done, improvement of results in quality seen from the quality of work done, trying to improve working time efficiency, trying to get useful work results. And it is necessary to increase job loyalty to the leadership. The employee's performance has not been able to make this happen under the realization of the set targets.

Regarding the observation gap regarding civil servants performance achieved, there needs to be a solution to improve employee performance through strengthening organizational commitment and several other causes that affect performance, including intelligence, local wisdom, and organizational culture by adopting the theory put forward, namely work result theory [2]. After comparing with several other theories related to performance, among others likes optimization theory (Douglas's), target theory (Philips's), goals theory (Stuggard's), profit theory (Samuelson's), valuation theory (Nelson's), and multiple functions theory (Algredo's). Among these theories, work is relevant theory (Fiedler's). This theory states that work results are real actualization of work results in quantity, quality, efficiency, effectiveness, and loyalty in achieving realization that exceeds the specified target.

It empirically shows that several things affect the performance of employees in carrying out their main tasks and functions properly according to government programs and activities, one of which is organizational commitment. On this basis, it is necessary to observe the phenomenon of organizational commitment built by the Wajo District Government at this time is still far from expectations. Employees do not understand the importance of affective as a commitment to advancing the organization, employees have not been able to implement normative as a commitment to carrying out various organizational rules, employees have not been able to develop continuous as a commitment to sustainability in realizing organizational goals and employees have not been able to maintain perspective commitment as a commitment to maintaining success that has been achieved [3], [4].

Evidence that employees' organizational commitment is still low can be seen from the lack of initiative of employees in advancing the organization, not complying with predetermined work rules, low efforts to develop the work given, and not the ability to maintain the results achieved. This fragile organizational commitment causes the achievement of employee performance to not achieve optimal results. Realizing this, the leadership of the organization must take a policy to implement a representative organizational commitment according to the dynamics of the organization. The theory used to address this is combining commitment theory and perspective [5] from a comparison of several theories, including compulsory theory, totality theory, sensitivity theory, and 
consequence theory. Both of these theories build organizational commitment based on work results and organizational goals. The elements built into this organizational commitment include affective, normative, continuous, and prospective elements as demands for realizing organizational goals [6].

Seeing this phenomenon in the Wajo district government shows that employee commitment and performance is still low due to the contribution of intelligence, local wisdom, and organizational culture from SKPD employees. The phenomenon of intelligence variables on organizational commitment and employee performance shows a gap that there are still many employees who do not have intelligence in emotional control, have not spiritual character according to religious teachings, are not intellectual in positive critical thinking, lack personality in behavior and have not interacted socially well. . The inability of employees to develop their potential intelligence affects their low organizational commitment and makes it difficult to achieve optimal employee performance.

The low of potential intelligence possessed by employees in facing and actualizing their work is a consideration for policymakers to apply on ESIPS theory (emotional, spiritual, intellectual, personality, and social) theory, after being compared with several theories, namely ratio theory. Grid, intellectual meta-theory Stobarch's, ESQ theory and judgment theory [7]. This theory suggests that everyone can develop their potential to be committed and perform to achieve their goals, must be able to manage their emotional, spiritual, intellectual, personality, and social intelligence properly in a directed manner according to their goals. It becomes a consideration to see the influence of intelligence that is given to employees with organizational commitment and employee performance aimed at organizational goals. This is the basis for seeing the urgency of the influence of intelligence on organizational commitment and employee performance [8].

The same thing shows that the occurrence of the phenomenon of local wisdom is also a consideration for the leadership to address this matter. Empirically, it can be seen that the habitual characteristics of the local community (local), are usually not used and placed proportionally in organizational activities that affect commitment and low performance. As there are still many employees who are considered to be dishonest (malempuk), less assertive (magetteng), lack of togetherness (pesse), lack of trust (tappe), and low self-esteem (siri') [9].

Empirical actualization of local wisdom that is less actualized is commonly seen, there are still employees who do not have honesty in their work, leaders who are less firm in directing subordinates, lack of togetherness in working together, diminishing trust in each other in work and lack of self-esteem for various failures at work. The actualization of local wisdom that is not in line with these highly respected characteristics and habits, makes many employees have low organizational commitment and performance [10].

This gap is certainly a consideration for organizational leaders to fix and provide strengthening local wisdom which must be developed into something that affects organizational commitment and employee performance. Through the application of the entity gap theory (Frechlin) and local, wisdom Quatrich theory (Wales'), among these theories the theory used is the theory of wisdom interpretation, that local community wisdom is an identity asset to build community commitment and performance. The relevance of this theory in government organizations is an interpretation that employees are required to have honesty, assertiveness, togetherness, confidence and self-respect to work well according to organizational commitment and continue to improve their performance [4].

Including organizational culture that has an influence on organizational commitment and employee performance, empirically it is found that the phenomenon in general government organizations as non-profit organizations has an organizational culture that is less professionally institutionalized. This is because organizational leadership is always changing. The change of each leader experiences a difference in the application of the organizational culture that is applied. Organizational culture is always a consideration to reinforce to employees in having an organizational commitment and achieving performance. The organizational, influences, culture that needs to be addressed is the lack of understanding of employees about the importance of integrity, identity, responsibility, discipline, and result policy makers policymakers, the orientation. The fact shows that there are employees who do not have high integrity in showing a big-minded attitude in responding to the work at hand, do not feel proud of their identity, are less responsible for the mandate given, lack of discipline in work and do not have a results-oriented culture. The low organizational culture makes the organization less institutionalized in realizing organizational commitment and achieving employee performance [11]-[13].

Responding to the fragility of the application of organizational culture, policy makers, in this case, the leaders, are required to foster the existence of organizational culture in increasing organizational commitment and employee performance. Through the application of the sensitivity gap theory, the theory of freedom, the theory of courage, and the theory of openness from Handy, the culture existence [14], that organizational culture is the existence of values that become the views of organizations in realizing organizational goals. Important elements that need to be put into practice in providing the existence of an organizational culture are fostering employee integrity, recognizing their true identity, being able to carry out mandate responsibilities, having work discipline, and being resultsoriented in their work. Policies to foster organizational culture are expected to contribute to organizational commitment and employee performance [15].

After understanding the above, this is linked to several previous studies to see the differences in the findings that can be recommended with this study, including the results of research conducted by [9], [11], [16]-[21]. Previous research has examined the variables of intelligence, local wisdom, organizational culture, commitment, and performance. The results of the research revealed from several of these studies, in general, found clear differences with this research, namely the use of observed variables, the reference to the variable theory used, there are several different indicators and the methodology used in determining the sample as respondents of the subject and object of research. 


\section{LITERATURE REVIEW AND HYPOTHESIS}

\section{A. Intelligence}

Intelligence is based on the ESIPS theory, that everyone can develop their potential to have a commitment and perform to achieve their goals, must be able to manage emotional, spiritual, intellectual, personality, and social intelligence [22].

$\mathrm{H}_{1}$ : Intelligence has a positive and significant effect on organizational commitment.

$\mathrm{H}_{4}$ : Intelligence has a positive and significant effect on civil servants' performance.

$\mathrm{H}_{8}$ : Intelligence has a positive and significant effect through an organizational commitment on civil servants' performance of Wajo district government.

\section{B. Local Wisdom}

Local wisdom refers to the local interpretation theory, that local community wisdom is an identity asset to build commitment and performance of employees in the organization. The relevance of this theory in government is an interpretation that employees are required to have honesty, assertiveness, togetherness, trust, and self-respect [23].

$\mathrm{H}_{2}$ : Local wisdom has a positive and significant effect on organizational commitment.

$\mathrm{H}_{5}$ : Local wisdom has a positive and significant effect on civil servants' performance of Wajo district government.

$\mathrm{H}_{9}$ : Local wisdom has a positive and significant effect through an organizational commitment on civil servants' performance of Wajo district government.

\section{Organizational Culture}

Organizational culture is a philosophy of normative habits that are rooted and become an assessment in advancing the organization. Assessment of organizational culture consists of five aspects of assessment, namely integrity, identity, responsibility, discipline, and results in orientation [24][26].

$\mathrm{H}_{3}$ : Organizational culture has a positive and significant effect on organizational commitment.

$\mathrm{H}_{6}$ : Organizational culture has a positive and significant effect on civil servants' performance of Wajo district government.

$\mathrm{H}_{10}$ : Organizational culture has a positive and significant effect through an organizational commitment on civil servants' performance of Wajo district government.

\section{Organizational Commitment}

Organizational commitment refers to the commitment appraising theory, that commitment is assessed based on the totality of behavior according to affective, normative, sustainable, and perspective commitment. The manifestation of affective commitment is committed to always being involved (participating), committed to developing the organization, committed to advancing the organization, the theory of the result, and maintaining organizational success [13].

\section{E. Civil Servants Performance}

Civil servant's performance refers to the results theory, that performance appraisal based on work activities is assessed based on the assumption of quantity according to the amount of work produced, quality according to the quality of work results, loyalty to leadership and organization, efficiency based on timeliness and effectiveness according to power [2].

$\mathrm{H}_{7}$ : Organizational commitment has a positive and significant effect on civil servants' performance of Wajo district government.

\section{RESEARCH METHODS}

This research is designed to answer the problems that have been formulated and the objectives to be achieved and to test the hypothesis. The research took two months with the location of the research carried out in the SKPD of the Wajo District Government because the object of this study was related to intelligence, local wisdom, and organizational culture on the commitment and performance of civil servants. There are two types of research, namely quantitative and qualitative research. Sources of data in this study consisted of primary and secondary data. The data collection techniques (instruments) used were observation, questionnaires, interviews, and documentation. The population in this study were all civil servants based on 115 SKPDs of the Wajo District Government totaling 5,991 people outside the honorary employees. The sample is a part of the population that is carefully selected to represent the population. Survey research is a study that takes a sample from a population and uses a questionnaire as a primary data collection tool by using the Slovin formula obtained a sample of 375 respondents. The data from the questionnaire were analyzed using the Structural Equation Model using AMOS 18 assistance.

\section{RESUlTS}

Based on the method of determining the value in the model, the variables for testing the results of the first evaluation model are grouped into exogenous variables and endogenous variables. An exogenous variable is a variable whose value is determined outside the model. Meanwhile, endogenous variables are variables whose value is determined through equations or from the results of the relationship evaluation model formed. Included in the group of exogenous variables are the measurement of intelligence, local wisdom and organizational culture, while those classified as endogenous variables are organizational commitment and performance.

The results of the evaluation model are said to be good if the theoretical development of a hypothetical model is supported by empirical data. The results of the complete SEM analysis can be seen in the following figure: 


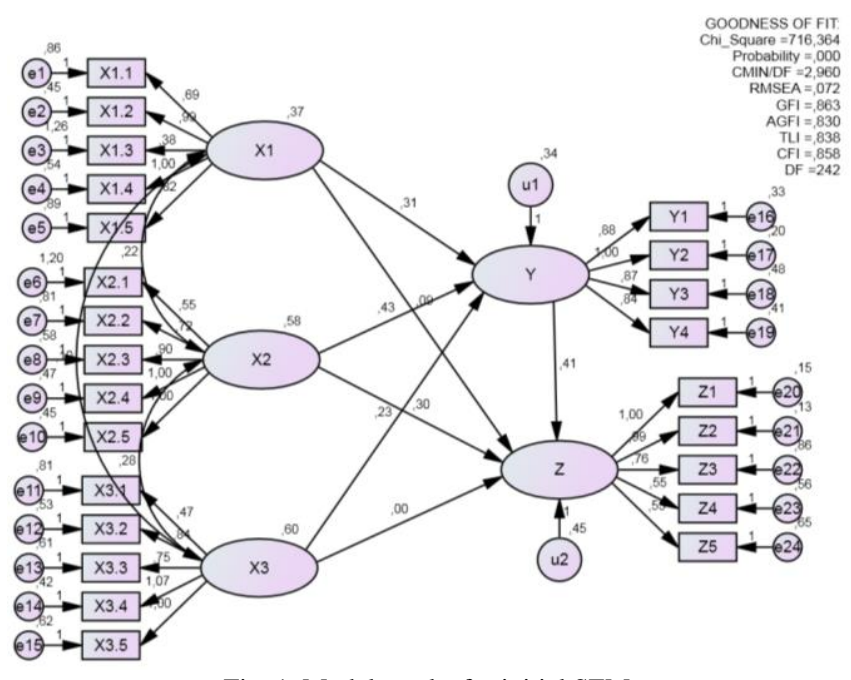

Fig. 1. Model results for initial SEM.

The results of the evaluation model show that from the eight criteria of goodness of fit indices, it can be seen that the chi-square value is still large, and it appears that some criteria do not match the value cutoff determined so that the modification of the model was carried out by correlating the error indicators according to the instructions of modification indices. The results of the analysis after the results of the final evaluation model obtained are as follows:

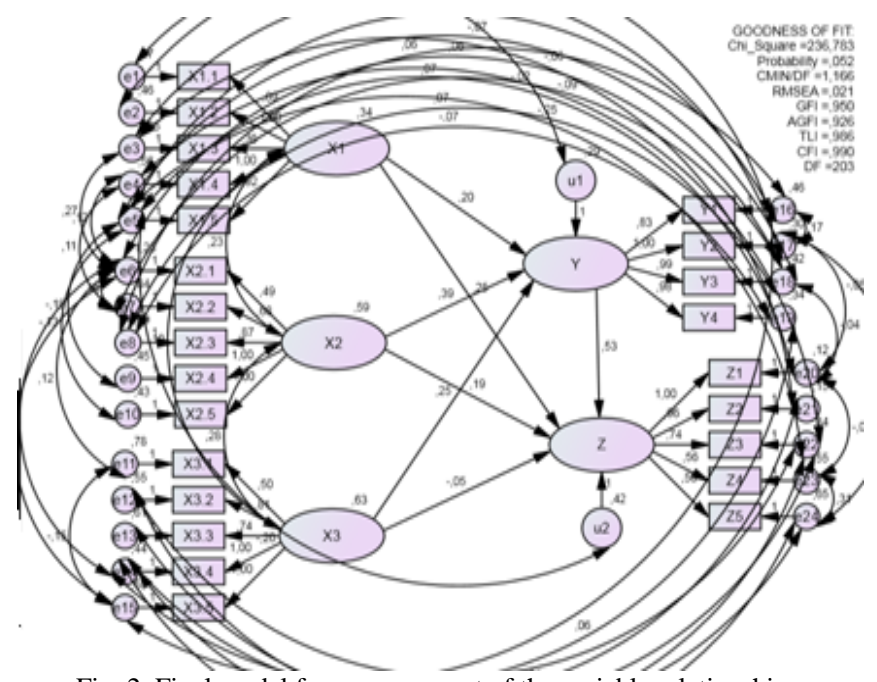

Fig. 2. Final model for measurement of the variable relationship.

Test results of the evaluation model are presented in Fig. 2 based on the goodness of fit indices in Table 2 by presenting the model criteria and their critical values that have conformity data between the standard cut off value standards late-stage and p-value besides the results of the early and late stage models.

TABLE II: GOODNESS OF FIT INDICES

\begin{tabular}{cccc}
\hline \multicolumn{4}{c}{ TABLE II: GOODNESS OF FIT INDICES } \\
\hline \multirow{2}{*}{ Chi_Square } & $\begin{array}{c}\text { Cut-off } \\
\text { Value }\end{array}$ & $\begin{array}{c}\text { Model Results } \\
\text { Early Stage }\end{array}$ & $\begin{array}{c}\text { Model Results } \\
\text { Final Stage }\end{array}$ \\
& Small & $716,364<(0.05: 242=$ & $236,783(0.05: 203=$ \\
Probability & $\geq 0.05$ & $279,287)$ & $237,240)$ \\
CMIN / DF & $\leq 2.00$ & 0,000 & 0.052 \\
RMSEA & $\leq 0.08$ & 2,960 & 1,166 \\
GFI & $\geq 0.90$ & 0.072 & 0.021 \\
AGFI & $\geq 0.90$ & 0.863 & 0.950 \\
TLI & $\geq 0.94$ & 0.830 & 0.926 \\
CFI & $\geq 0.94$ & 0.838 & 0.986 \\
\hline \multicolumn{2}{c}{ DF } & 0.858 & 0,990 \\
\hline \hline
\end{tabular}

The results of the evaluation model for the early stage show of the eight criteria of goodness of fit indices have not met the criteria cut off value, so it is necessary to modify the results of the model according to the instructions of modification indices. Modification Indices (MI) is a calculation to make changes to numbers, where the numbers below indicate the minimum value of chi-square that will decrease if the corresponding variables are connected. After modifying the model, the final stage shows that the eight criteria have met the goodness of fit indices or according to the cut off value, so that the model can be said to have met the criteria for goodness of fit indices to be analyzed.

Based on the empirical model proposed in this study, the hypothesis proposed by testing the path coefficient on the structural equation model can be tested. Table 3 is a hypothesis testing by looking at the $\mathrm{p}$ value, if the $\mathrm{p}$ value is less than 0.05 , the relationship between the variables is significant. In addition, it also explains the direct effect, meaning that there is a direct positive influence between variables. Indirect effect means that there is a positive between the total variables, and the total effect, namely the accumulation of direct and indirect effects. The test results are presented in the following table:

TABLE III: DIRECT, INDIRECT AND TOTAL EFFECT

\begin{tabular}{|c|c|c|c|c|c|c|}
\hline Indp. & $\begin{array}{c}\text { Variable } \\
\text { Interv. }\end{array}$ & Dep. & Direct & Indirect & Total & P-value \\
\hline Intll. & - & $\mathrm{OC}$ & 0.165 & - & 0.165 & 0.031 \\
\hline LW & - & $\mathrm{OC}$ & 0.408 & - & 0.408 & 0.000 \\
\hline Cul. & - & $\mathrm{OC}$ & 0.274 & - & 0.274 & 0.000 \\
\hline Intll. & - & CSP & 0.173 & - & 0.173 & 0.027 \\
\hline LW & - & CSP & 0.174 & - & 0.174 & 0.032 \\
\hline Cul. & - & CSP & -0.043 & - & -0.043 & 0.488 \\
\hline OC & - & CSP & 0.452 & - & 0.452 & 0.000 \\
\hline Intll. & $\mathrm{OC}$ & CSP & 0.165 & 0.075 & 0.240 & 0.044 \\
\hline LW & $\mathrm{OC}$ & CSP & 0.408 & 0.185 & 0.593 & 0.000 \\
\hline Cul. & $\mathrm{OC}$ & CSP & 0.274 & 0.124 & 0.398 & 0.001 \\
\hline
\end{tabular}

Looking at the p-value results on the effect of the indirect effect of independent variables through intermediate variables on the dependent variable in SEM analysis shows a positive and significant effect, so to prove the indirect effect, then the Sobel test [27], with the following calculation results:

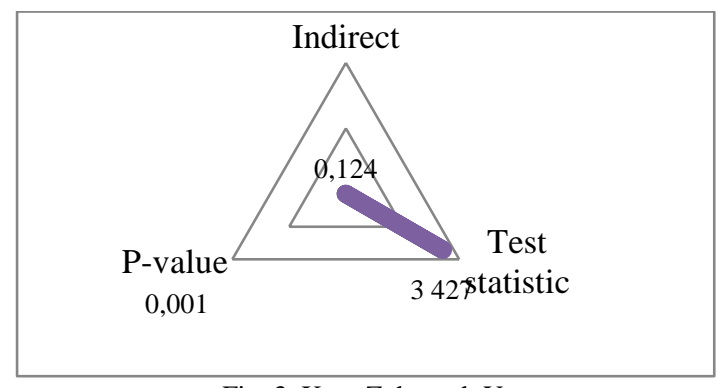

Fig. 3. $\mathrm{X}_{1}$ to $\mathrm{Z}$ through $\mathrm{Y}$.

Intelligence indirectly through influential organizational commitment positive and significant towards employee performance with SEM results for Standardized Indirect Effect of 0.075 with Sobel test results of 2.014 and p-value $=0.044>0.05$. 


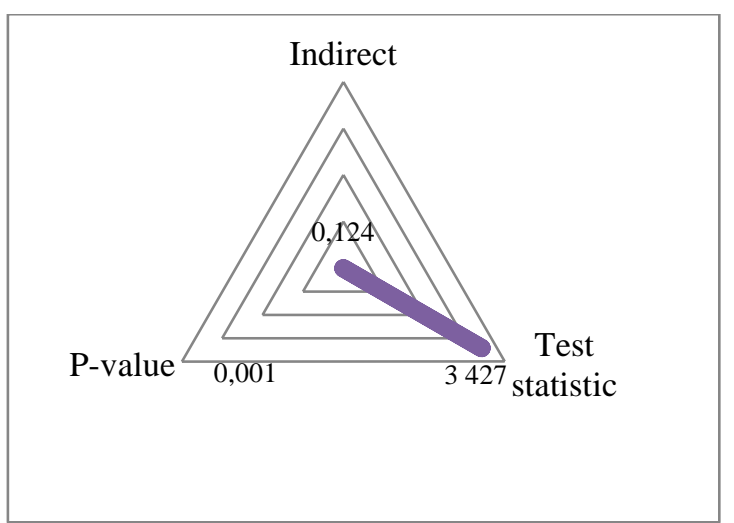

Fig. 4. $X_{2}$ to $Z$ through $Y$.

Local wisdom indirectly through organizational commitment has a positive and significant effect on employee performance with SEM results for Standardized Indirect Effect of 0.185 with Sobel test results of 3,749 and $\mathrm{p}$-value $=0.000>0.05$.

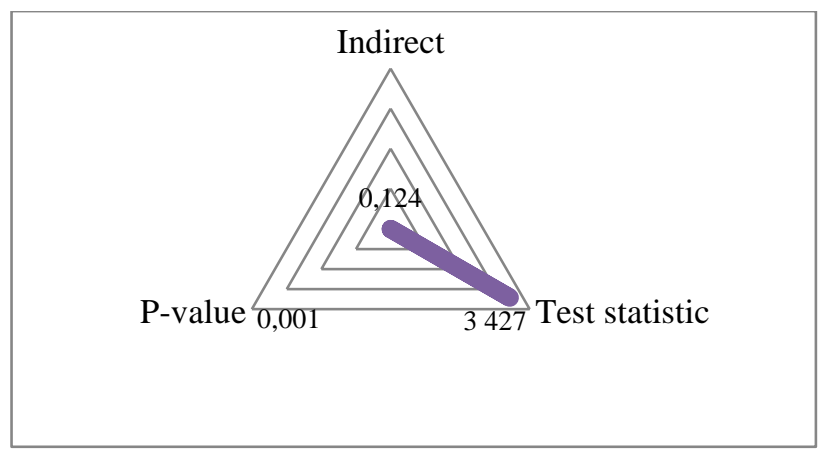

Fig. 5. $\mathrm{X}_{3}$ to $\mathrm{Z}$ through $\mathrm{Y}$.

Organizational culture indirectly through organizational commitment has a positive and significant effect on employee performance with SEM results for the Standardized Indirect Effect of 0.124 with Sobel test results of 3,427 and p-value $=0.001>0.05$.

The overall model of the seven direct paths and three indirect paths is hypothesized. Based on the results of SEM AMOS analysis, there are six direct pathways that have a positive and significant effect, and one direct path has a negative and insignificant effect. Meanwhile, the results of the Sobel test analysis for the indirect effect showed a positive and significant effect.

The interpretation of Table 3 can be explained that the intelligence has a direct influence on organizational commitment with acoefficient value direct effect of 0.165 and $p=0.031<0.05$, indicating that intelligence contributes positively and significantly to the organizational commitment of Wajo District Government employees. Local wisdom has a direct influence on organizational commitment with acoefficient direct effect of 0.408 and $\mathrm{p}=$ $0.000<0.05$, indicating that intelligence contributes positively and significantly to the organizational commitment of Wajo District Government employees. Organizational culture has a direct influence on organizational commitment with acoefficient direct effect of 0.274 and $p=0.000<0.05$, indicating that intelligence contributes positively and significantly to the organizational commitment of Wajo District Government employees.

The other results showing the intelligence has a positive and significanton performance with acoefficient value direct effectdirect effect of 0.173 and $p=0.027<0.05$, indicating that intelligence contributes to the performance of Wajo District Government employees. Local wisdom has a direct effect on performance with acoefficient direct effect of 0.174 and $p=0.032<0.05$, indicating that local wisdom has a positive and significant contribution to the performance of Wajo District Government employees. Meanwhile, the organizational culture has a direct effect on performance with acoefficient direct effect of -0.043 and $p=0.488>0.05$, indicating that intelligence contributes negatively and is not significant to the performance of Wajo District Government employees. Organizational commitment has a direct effect on performance with acoefficient direct effect of 0.452 and $\mathrm{p}=0.0000<0.05$, indicating that organizational commitment has a positive and significant contribution to the performance of Wajo District Government employees.

The result of intervening variable proved that the intelligence through organizational commitment has an indirect effect on the performance of Wajo District Government employees with a coefficient value the result of SEM analysis of AMOS indirect effect is 0.075 . While the results of the calculation through the sobel test were obtained for 2014 with a significance level of $\mathrm{p}$, namely $0.044<0.05$ (significant), proving that intelligence contributes through organizational commitment which indirectly has a positive and significant effect on employee performance. Local wisdom through organizational commitment has a positive and significant indirect effect on the performance of Wajo District Government employees with a coefficient value the result of SEM analysis of AMOS indirect effect is 0.185 . Meanwhile, the results of the calculation through the Sobel test obtained 3,749 with a significance level of $\mathrm{p}$, namely $0.000<0.05$ (significant), proving that local wisdom through organizational commitment indirectly has a positive and significant effect on employee performance and organizational culture through organizational commitment has a positive and significant indirect effect on the performance of Wajo District Government employees with a coefficient value. the result of SEM analysis of AMOS indirect effect is 0.124 . While the results of the calculation through the Sobel pvalue test (Sobel test) was obtained for 3,427 with a significance level of $\mathrm{p}$, namely $0.001<0.05$ (significant), proving that organizational culture through organizational commitment indirectly has a positive and significant effect on employee performance.

\section{CONCLUSION}

Intelligence has a positive and significant effect on employee commitment. This implies that all indicators of intelligence in the form of emotional, spiritual, personal, and social are owned by each employee in making a significant contribution to the realization of employee commitment. Local wisdom has a positive and significant impact on commitment. This means that all indicators in the form of honesty, assertiveness, togetherness, trust, and self-esteem together provide a positive influence strengthening in increasing employee local wisdom and this contributes significantly to increased employee commitment. 
Organizational culture has a positive and significant effect on commitment. This indicates that all indicators of organizational culture in the form of integrity, identity, responsibility, discipline and results in orientation simultaneously reinforce the organizational culture positively, as well as make a real contribution to increasing employee commitment. Intelligence directly has a positive and significant impact on employee performance. This implies that the existence of intelligence indicators as a whole has a positive influence in strengthening the existence of potential intelligence of employees and makes a significant contribution to improving employee performance.

The local wisdom has a positive and significant impact on employee performance. This implies that the indicators of local wisdom shown by employees are actualized in strengthening the positive influence and making a significant contribution to employee performance. Organizational culture has a negative and insignificant effect on performance. This means not proving the hypothesis proposed. This means that the indicators of organizational culture collectively do not have a strengthening effect on organizational culture so that their contribution is not significant to performance. Organizational commitment directly has a positive and significant impact on employee performance, which means that the proposed hypothesis is proven. The meaning of the results of this study can be interpreted that the indicators of affective, normative, sustainable commitment and the perspective applied so far have been maximal so that they have a positive and significant impact on employee performance. Intelligence through commitment has a positive and significant impact on employee performance. This shows that employees have committed to work and this is a must that employees must demonstrate to improve their performance. Local wisdom through commitment has a positive and significant effect on employee performance. Employee local wisdom in the form of honest, assertive behavior, togetherness, trust, and selfesteem from employees is good and supports the improvement of employee local wisdom through a commitment to performance. This implies that employees' local wisdom is further enhanced so that each employee is committed to improving their performance, and organizational culture through commitment has a positive and significant effect on employee performance. This means that the organizational culture possessed by employees is indirectly decisive in increasing employee commitment and performance.

\section{REFERENCES}

[1] Susilo, M. (2007). Human resources management. Chapter 5. First Edition. BPFE. Yogyakarta.

[2] Fiedler, R. Wayne. (2018). Human Resource Management, Allyn \& Bacon.

[3] Sjahruddin, H., \& Normijati, A. A. S. (2013). Personality effect on organizational citizenship behavior (OCB): trust in manager and organizational commitment mediator of organizational justice in Makassar City Hospitals (Indonesia). European Journal of Business and Management, 5(9), 95-104.

[4] Frechlin, Adam. (2018). Human Resource Management. West Publishing Company, New York.

[5] Smith, Charvert and Meyer, G. (2017). The Good Perspective Theory for Commitment Organization. Prentice-Hall, Ohio University Press.
[6] Kanto, M., \& Sjahruddin, H. (2020). How psychological capital mediates the relationship between thriving at work and happiness at work? A cross-sectional research for tourism sector of indonesia. PalArch's Journal of Archaeology of Egypt/Egyptology, 17(6), 17981812.

[7] Goleman, Daniel. (2017). Potential Intelligence. PT Gramedia Pustaka Utama, Jakarta.

[8] Goleman, Daniel. (2018). Primal Leadership: Realizing the Power of Potential Intelligence. Harvard Business School Press, Boston.

[9] Ardi, Kusumawardhana. (2006). The Influence of Intelligence, Organizational Culture on Motivation and Performance of Processed Wood Industry Employees in Makassar City, South Sulawesi. Dissertation of PPS UMI Makassar.

[10] Sjahruddin, H., \& Sudiro, A. A. (2013). Organizational justice, organizational commitment and trust in manager as predictor of organizational citizenship behavior. Interdiciplinary J. of contemporary Res. Bus. (IJCRB), 4(12), 133-141.

[11] Bartex, Birney. (2011). Analysis of Potential intellectual, Local wisdom, Motivation and Organization Culture toward Organization commitment to Increasing the Performance of Employee in Florida Government. International Journal of Management 29 (2011) 33-44.

[12] Bill, Roberts. (2018). Affect of Motivation, Local wisdom, Culture toward Commitment and Performance and Correlation with Increasing Human Resource Quality in Scientific Software International Inc. Chicago. European Journal of Business and Social Sciences. Vol. 1 No. 2 pp 35-47.

[13] Buddy, Wilson. (2018). Affect Organization Commitment, Culture in Work and Leadership toward Performance and Satisfaction. International Journal Business Management, Vol. 3, No. 3, 1-15.

[14] Robbins, Stephen, P. (2015). Organizational Behavior. PrenticeHallPrentice-Hall, Cliffs, New Jersey.

[15] Hasanuddin, R., \& Sjahruddin, H. (2017). The structure of emotional intelligence, spiritual intelligence and its relationship with work enthusiasm and auditor performance. Structure, 3(1), 67-85.

[16] Shalma, Sarindah. (2016). The Influence of Intelligence, Organizational Culture and Motivation on Organizational Commitment and Performance, Studies at PT. Astra Agro Lestari Tbk. Jakarta. Dissertation of PPS Universitas Brawijaya Malang.

[17] Lyra, Sumantoro. (2016). Analysis of Performance Analysis of Medical Personnel Services to Increasing Patient Organizational Commitment at Dharmais Hospital Jakarta. Dissertation of PPS Universitas Brawijaya Malang.

[18] Yoshep, Damascus. (2011). Effect of Local wisdom, Corporate Culture, and Organization commitment toward Performance. Journal of Vocational Behavior 76 (2011) 458-473.

[19] Nikpour, Amin. (2017). The impact of organizational culture on organizational performance: The mediating role of employee's organizational commitment. International Journal of Organizational Leadership, 6, 65-72.

[20] Simonne, Solomon. (2018). Analysis of Organization Commitment, Culture, and Discipline toward Morality and Performance by Lecture of San Francisco University. International Journal Business Management, Vol. 3, No. 3, 1-15.

[21] Toban, C., \& Sjahruddin, H. (2016). The antecedent and consequence of Organizational Commitment and Job Satisfaction. Journal of Business and Management Sciences, 4(2), 26-33.

[22] Goleman, Daniel. (2010). Working With Potential Intelligence. PT Gramedia Pustaka Utama, Jakarta.

[23] Jane, Mathew. (2020). Role Of Spiritual Intelligence And Occupational Stress On Organizational Commitment: Evidence From Outsourcing Industry. Journal of Critical Reviews, ISSN: 2394-5125 Vol 7 Issue 6.

[24] Robbins, Stephen, P. (2016). Organization Theory: Structure Designs and Applications. Prentice Hall Int Ed. Englewood Cliffs, New Jersey

[25] Sifatu, W. O., Sjahruddin, H., Fajriah, Y., Dwijendra, N. K. A., \& Santoso, A. (2020). Innovative Work Behaviors in Pharmacies of Indonesia: Role of Employee Voice, Generational Diversity Management and Employee Engagement. Systematic Reviews in Pharmacy, 11(2), 725-734.

[26] Suharto, (2019). The Impact of Organizational Commitment on Job Performance. International Journal of Economics and Business Administration Volume VII, Issue 2.

[27] Kim, J., Hwang, E., Phillips, M., Jang, S., Kim, J. E., Spence, M. T., $\&$ Park, J. (2018). Mediation analysis revisited: Practical suggestions for addressing common deficiencies. Australasian Marketing Journal (AMJ), 26(1), 59-64. 